\section{Germline mutation analysis of the transforming growth factor $\beta$ receptor type II (TGFBR2) and E-cadherin $(C D H 1)$ genes in early onset and familial colorectal cancer}

EDITOR-Genetic factors are clearly implicated in colorectal cancer (CRC) susceptibility, with $10 \%$ of all cases having an affected first degree relative and suggestions that up to $20 \%$ of all colorectal cancers occur in susceptible people. Identification of the molecular basis for familial adenomatous polyposis (FAP) and hereditary nonpolyposis colon cancer syndrome (HNPCC) has provided insights into the mechanisms of colorectal cancer susceptibility and illustrated how somatic mutations in familial cancer genes are frequently implicated in sporadic cancers. FAP has a characteristic phenotype with profuse colorectal polyposis, and although variant attenuated forms of FAP are described, germline APC gene mutations are a rare cause of colorectal cancer. HNPCC is characterised by early onset CRC and, in some kindreds, endometrial, gastric, ovarian, pancreatic, and urinary tract cancers. ${ }^{1}$ Germline mutations in mismatch repair genes (MMR) such as MSH2, MLH1, PMS1, PMS2, and MSH6 account for many, but not all, HNPCC kindreds. Most (>90\%) HNPCC kindreds with germline MMR mutations have a MSH2 or MLH1 mutation. Germline MMR gene mutations have also been described in isolated early onset colorectal cancer (EOCRC) or familial non-HNPCC CRC. ${ }^{2-4}$ However, it is estimated that FAP and HNPCC only account for $\sim 3 \%$ of CRC cases and studies of early onset and non-HNPCC familial cases have indicated that most such cases do not have germline MMR gene mutations or evidence of tumour microsatellite instability (MSI) (the hallmark of tumour MMR gene inactivation). ${ }^{2}{ }^{4-6}$ Candidate gene approaches to identify further genes for early onset and familial CRC have been largely unsuccessful. Thus, mutation analysis of $\beta$-catenin and $S M A D 2, S M A D 3$, and $S M A D 4$ have been unrewarding. ${ }^{78}$ Transforming growth factor $\beta(\mathrm{TGF}-\beta)$ inhibits the growth of colorectal cancer cell lines through the type II receptor (TGF- $\beta$ RII) encoded by the TGFBR2 gene. Inactivation of TGFBR2 is frequent in colorectal cancers with MMR gene inactivation because of MSI in a poly A tract within the gene. ${ }^{9-11}$ In addition, somatic mutations of TGFBR2 are frequent in microsatellite stable (MSS) colorectal cancers. ${ }^{12}$ Although germline TGFBR2 mutation has been described in familial CRC, ${ }^{13}$ the contribution of germline TGFBR2 mutations to colorectal cancer susceptibility is not well defined.

Somatic mutations in the E-cadherin gene $(\mathrm{CDH} 1)$ are frequent in colorectal and other cancers, including gastric, breast, prostate, and ovary. ${ }^{14-18} \mathrm{E}$-cadherin is a homophilic cell adhesion molecule whose binding to $\beta$-catenin at adherens junctions prevents $\beta$-catenin mediated cell signalling. Loss of E-cadherin function leads to increased cell mobility and increased activity of the $\beta$-catenin/TCF transcription factor complex in the nucleus. ${ }^{19}$ Germline CDH1 mutations are associated with familial diffuse type gastric cancer. ${ }^{20}$ In addition, we and others have reported
EOCRC in patients with germline CDH1 mutations. ${ }^{21} 22$ However, the possible contribution of germline $C D H 1$ mutations to familial and early onset CRC is unknown. We therefore investigated cohorts of EOCRC and kindreds with familial CRC for germline TGFBR2 and CDH1 mutations.

Genomic DNA from 67 patients with EOCRC at $<55$ years of age and probands from 20 familial CRC cases were investigated. The age distribution of the 67 cases is shown in fig 1 . For 48 of 67 cases, tumour microsatellite instability (MSI) status had been determined as described previously ${ }^{4}$ and 39 of the 48 cases showed no evidence of MSI. ${ }^{23}$ All 20 familial CRC cases were from kindreds fulfilling the Amsterdam criteria for HNPCC, ${ }^{24}$ but in whom mutation screening by single stranded conformation polymorphism (SSCP) analysis for germline $\mathrm{MSH} 2$ and MLH1 mutations was negative. TGFBR2 mutation analysis of the 67 EOCRC and 20 familial CRC cases was carried out using 10 sets of primers that amplified the entire exon 7 coding region as described by Lu et al. ${ }^{25}$ PCRs were carried out in standard buffer, 1.5-2.0 mmol/1 $\mathrm{MgCl}_{2}, 0.2$ mmol/1 dNTPs, 10-20 pmol of each primer, 1 unit of Taq polymerase, and $100 \mathrm{ng}$ DNA per $25 \mu \mathrm{l}$ reaction, for 35 cycles $\left(95^{\circ} \mathrm{C}\right.$ for one minute, $55-57^{\circ} \mathrm{C}$ for one minute, $72^{\circ} \mathrm{C}$ for one minute), with a final elongation step of $72^{\circ} \mathrm{C}$ for 10 minutes, in an OmnE thermal cycler (Hybaid Ltd). For exon 3, to prevent false positives caused by Taq polymerase slippage errors at the polyA repeat, the proof reading polymerase Pfu Turbo (Stratagene) was used and all samples were directly sequenced as well as undergoing SSCP analysis.

Twenty three of the EOCRC aged $<45$ years and the 20 HNPCC probands were screened for germline CDH1 mutations by PCR-SSCP analysis of all 16 exons as described previously by Richards et al. ${ }^{21}$

SSCP analysis was performed using $20 \mathrm{~cm} 8 \%$ polyacrylamide, $5 \%$ glycerol, $0.5 \times \mathrm{TBE}$ gels, electrophoresed at 1 W for $12-15$ hours at $4^{\circ} \mathrm{C}$, followed by silver staining. For DNA sequencing, PCR products were purified using a presequencing reagent pack (Amersham Pharmacia Biotech), or Wizard PCR Preps (Promega, Southampton, UK) and sequenced using the PRISM dRhodamine dye terminator cycle sequencing kit (PE-Applied Biosystems) on an ABI 377 automated sequencer.

SSCP analysis did not show any TGFBR2 abnormality in the 87 patients tested, suggesting that germline TGFBR2 mutations are not frequent in $M S H 2 / M L H 1$ mutation negative HNPCC cases or in CRC cases affected before 55

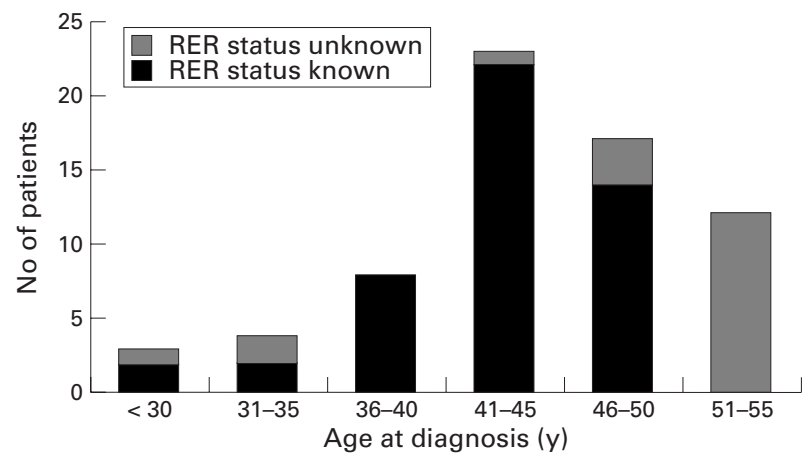

Figure 1 Chart to show total number of EOCRC patients analysed for TGFBRII mutations and microsatellite instability status. 
years. As a small false negative rate may be associated with SSCP analysis, we proceeded to sequence exon 3 (a hot spot for somatic TGFBR2 mutations) in all 87 patients; however, no abnormality was detected in any case.

No germline mutation was detected in $C D H 1$ in any of the 43 cases tested but several polymorphisms were identified. The exon 4 PCR product contained an intronic $\mathrm{C}(531+10) \mathrm{G}$ SNP in three of 43 cases (two EOCRC and one HNPCC). We then examined 30 normal controls and detected a further seven heterozygotes for the $C D H 1$ $531+10 \mathrm{G}$ variant. Thus, there were no differences between the frequency of the $\mathrm{C}(531+10) \mathrm{G}$ SNP in EOCRC (2/23), familial cases (1/20), and normal controls. In addition, an exon $13 \mathrm{CDH} 1 \mathrm{C} 2076 \mathrm{~T}$ variant was identified in 9/23 EOCRC and 9/20 HNPCC cases. This silent variant has been reported previously as a polymorphism. ${ }^{21}{ }^{26}$ A further polymorphism was detected by sequencing the exon 13 PCR products: C/T (1937-13) in intron $12 ; 5 / 17$ HNPCC patients were homozygous T-T, $11 / 17$ were heterozygous, and 1/17 was homozygous C-C. This polymorphism has also been previously reported. ${ }^{2126}$

In summary, we did not detect evidence to suggest that germline $T G F B R 2$ or $C D H 1$ mutations are a frequent occurrence in patients with EOCRC or HNPCC. We did not detect germline TGFBR2 mutations in EOCRC and HNPCC cases without $M S H 2$ or $M L H 1$ mutations. Although a germline TGFBR2 mutation has been described previously in one HNPCC-like kindred, the onset of colon carcinoma in the three affected subjects in that family was $>50$ years in all cases. ${ }^{13}$ Hence, further studies of a large number of EOCRC and HNPCC cases will be needed to exclude a role for infrequent $T G F B R 2$ mutations in these cases, and the role of TGFBR2 mutations should also be investigated in kindreds with familial late onset CRC who do not satisfy the Amsterdam criteria. Similarly, as EOCRC is a feature of a germline $C D H 1$ mutation in some kindreds, ${ }^{21}{ }^{22}$ further studies are required to exclude a role of infrequent germline $C D H 1$ mutations in EOCRC cases.

We thank the West Midlands NHS Executive, the Birmingham United Hospital Fund, and the British Digestive Foundation for financial support.

LOVEENA VERMA* TIMOTHY R PORTER ${ }^{\star}$ FRANCES M RICHARDS* $M$ HELEN RAJPAR * D GARETH R EVANS + FIONA MACDONALD EAMONN R MAHER $‡$

${ }^{\star}$ Section of Medical and Molecular Genetics, Department of Paediatrics and Child Health, University of Birmingham, Edgbaston, Birmingham B15 2TG, UK

†Department of Medical Genetics, St Mary's Hospital, Manchester, UK $\ddagger$ West Midlands Regional Genetics Service, Birmingham Women’s Hospital, Edgbaston, Birmingham B15 2TG, UK

Correspondence to: Professor Maher, ermaher@hgmp.mrc.ac.uk

1 Lynch HT, de la Chapelle A. Genetic susceptibility to non-polyposis colorectal cancer. 7 Med Genet 1999;36:801-18.

2 Liu B, Farrington SM, Petersen GM, Hamilton SR, Parsons R, Papadopoulos N, Fujiwara T, Jen J, Kinzler KW, Wyllie AH, Vogelstein B, Dunlop MG. Genetic instability occurs in the majority of young patients with colorectal cancer. Nat Med 1995;1:348-52.
3 Peltomaki P, Vasen HF. Mutations predisposing to hereditary nonpolyposis colorectal cancer: database and results of a collaborative study. The Inter-
national Collaborative Group on Hereditary Nonpolyposis Colorectal national Collaborative Group on Heredit
Cancer. Gastroenterology 1997;113:1146-58.

4 Verma L, Kane MF, Brassett C, Schmeits J, Evans DGR, Kolodner RD, Maher ER. Mononucleotide microsatellite instability and germline MSH6 mutation analysis in early onset colorectal cancer. 7 Med Genet 1999;36:678-82.

5 Tomlinson IPM, Beck NE, Homfray T, Harocopos CJ, Bodmer WF. Germline HNPCC gene variants have little influence on the risk for sporadic colorectal cancer. 7 Med Genet 1997;34:39-42.

6 Brassett C, Joyce JA, Froggatt NJ, Williams G, Furniss D, Walsh S, Miller R, Evans DGR, Maher ER. Microsatellite instability in early onset and familial colorectal cancer. F Med Genet 1996;33:981-5.

7 Dobbie Z, Muller H. Germline mutations in the beta-catenin gene are not associated with the FAP phenotype without an APC mutation. 7 Med Genet 1999;36:573-4.

8 Roth S, Johansson M, Loukola A, Peltomaki P, Jarvinen H, Mecklin JP, Aaltonen LA. Mutation analysis of SMAD2, SMAD3 and SMAD4 genes in
hereditary non-polyposis colorectal cancer. F Med Genet 2000;37:298-301.

9 Markowitz S, Wang J, Myeroff L, Parsons R, Sun LZ, Lutterbaugh J, Fan RS, Zborowska E, Kinzler KW, Vogelstein B, Brattain M, Willson JKV. Inactivation of the type-II tgf-beta receptor in colon-cancer cells with microsatellite instability. Science 1995;268:1336-8.

10 Parsons R, Myeroff LL, Liu B, Willson JKV, Markowitz SD, Kinzler KW, Vogelstein B. Microsatellite instability and mutations of the transforming growth-factor-beta type-II receptor gene in colorectal-cancer. Cancer Res 1995;55:5548-50.

11 Lu SL, Akiyama Y, Nagasaki H, Saitoh K, Yuasa Y. Mutations of the transforming growth-factor-beta type-II receptor gene and genomic instability in hereditary nonpolyposis colorectal-cancer. Biochem Biophys Res Commun 1995;216:452-7.

12 Grady WM, Myeroff LL, Swinler SE, Rajput A, Thiagalingam S, Lutterbaugh JD, Neumann A, Brattain MG, Chang J, Kim SJ, Kinzler KW, Vogelstein B, Willson JKV, Markowitz, S. Mutational inactivation of transforming growth factor beta receptor type II in microsatellite stable colon cancers. Cancer Res 1999;59:320-4.

$13 \mathrm{Lu}$ SL, Kawabata M, Imamura T, Akiyama Y, Nomizu T, Miyazono K, Yuasa Y. HNPCC associated with germline mutation in the TGF-beta type II receptor gene. Nat Genet 1998;19:17-18.

14 Becker KF, Atkinson MJ, Reich U, Becker I, Nekarda H, Siewert JR, Hofler $\mathrm{H}$. E-cadherin gene mutations provide clues to diffuse type gastric carcinomas. Cancer Res 1994;54:3845-52.

15 Berx G, Cleton-Jansen AM, Nollet F, de Leeuw WJ, van de Vijver M, Cornelisse C, van Roy F. E-cadherin is a tumour/invasion suppressor gene mutated in human lobular breast cancers. EMBO f 1995;14:6107-15.

16 Ilyas M, Tomlinson IP, Hanby A, Talbot IC, Bodmer WF. Allele loss, replication errors and loss of expression of E-cadherin in colorectal cancers. Gut 1997;40:654-9.

17 Risinger JI, Berchuck A, Kohler MF, Boyd J. Mutations of the E-cadherin gene in human gynecologic cancers. Nat Genet 1994;7:98-102.

18 Graff JR, Herman JG, Lapidus RG, Chopra H, Xu R, Jarrard DF, Isaacs WB, Pitha PM, Davidson NE, Baylin SB. E-cadherin expression is silenced by DNA hypermethylation in human breast and prostate carcinomas. Cancer Res 1995;55:5195-9.

19 Christophori G, Semb H. The role of the cell adhesion molecule E-cadherin as a tumour suppressor gene. Trends Biol Sci 1999;24:73-6.

20 Caldas C, Carneiro F, Lynch HT, Yokota J, Wiesner GL, Powell SM, Lewis FR, Huntsman DG, Pharoah PDP, Jankowski JA, MacLeod P, Vogelsang H, Keller G, Park KGM, Richards FM, Maher ER, Gayther SA, Oliveira C, Grehan N, Wight D, Seruca R, Roviello F, Ponder BAJ, Jackson CE. Familial gastric cancer: overview and guidelines for management. $f$ Med Genet 1999;36:873-80

21 Richards FM, McKee SA, Rajpar MH, Cole TRP, Evans DGR, Jankowski JA, McKeown C, Sanders DSA, Maher ER. Germline E-cadherin gene (CDH1) mutations predispose to familial gastric cancer and colorectal cancer. Hum Mol Genet 1999;8:607-10.

22 Guilford P, Hopkins J, Harraway J, McLeod M, McLeod N, Harawira P, Taite H, Scoular R, Miller A, Reeve AE. E-cadherin germline mutations in familial gastric cancer. Nature 1998;392:402-5.

23 Boland CR, Thibodeau SN, Hamilton SR, Sidransky D, Eshleman JR, Burt RW, Meltzer SJ, Rodriguez-Bigas MA, Fodde R, Ranzani GN, Srivastava S. A National Cancer Institute Workshop on microsatellite instability for cancer detection and familial predisposition: development of international criteria for the determination of microsatellite instability in colorectal cancer. Cancer Res 1998;58:5248-57.

24 Vasen HFA, Mecklin JP, Khan PM, Lynch HT. The InternationalCollaborative-Group-On-Hereditary-Non-Polyposis-Colorectal-Cancer (Icg-Hnpcc). Dis Colon Rectum 1991;34:424-5.

25 Lu SL, Zhang WC, Akiyama Y, Nomizu T, Yuasa Y. Genomic structure of the transforming growth factor beta type II receptor gene and its mutations in hereditary nonpolyposis colorectal cancers. Cancer Res 1996;56:4595-8.

26 Berx G, Becker KF, Hofler H, van Roy, F. Mutations of the human E-cadherin (CDH1) gene. Hum Mutat 1998;12:226-37. 